\title{
PEDOMAN PENULISAN
}

Jurnal Planta Tropika menerima naskah dalam bentuk hasil penelitian, catatan penelitian, artikel ulasan, dan ulas balik (review.mini review), dan baik dalam bahasa Indonesia maupun bahasa Inggris.

Penulis diminta mengirimkan tiga eksemplar naskah kepada editor yang dilengkapi dengan disket berisi naskah tersebut dan penulis akan mendapat tiga cetak lepas setelah terbit. Naskah diketik dengan program Microsoft. Naskah dan disket dikirim ke :

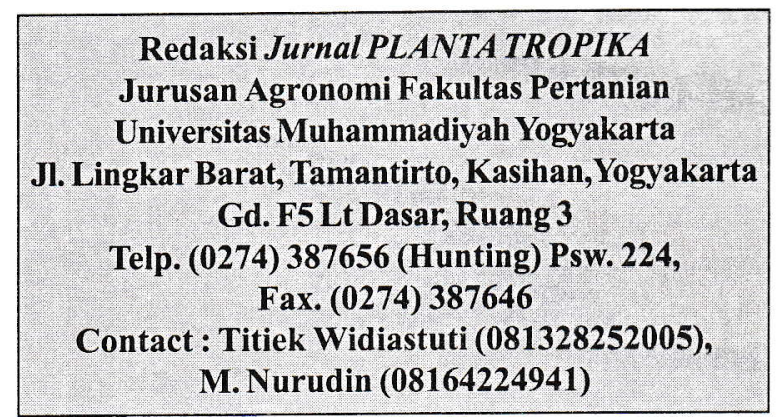

Naskah diketik 2 (dua) spasi pada kertas HVS ukuran kwarto dengan pias 2 centimeter dengan huruf bertipe Times New Roman berukuran 12 point. Setiap halaman diberi nomor secara berurutan. Gambar dan tabel dikelompokkan bersama di bagian akhir naskah pada lembaran terpisah.

- Naskah hasil penelitian disusun dengan urutan sebagai berikut:

a. Judul dalam bahasa Indonesia dan Inggris untuk artikel dalam bahasa Indonesia, dan judul dalam bahasa Inggris untuk artikel berbahasa Inggris.

b. Nama lengkap penulis.

c. Nama lembaga/institusi, disertai alamat lengkap dengan nomor kode pos.

d. Nama penulis untuk korespondensi dilengkapi telepon, fax dan e-mail.

e. Judul pelari (Running title)

f. Abstrak dalam bahasa Inggris (tidak lebih dari 200 kata)

g. Kata kunci dalam bahasa Inggris

h. Pendahuluan

i. Bahan dan Metode (Metode Penelitian)

j. Hasil dan Pembahasan

k. Kesimpulan

1. Ucapan terima kasih (jika diperlukan)

m. Daftar pustaka

n. Gambar dan tabel, beserta keterangannya.

- Catatan hasil penelitian, ulasan, dan ulas balik, ditulis sebagai naskah sinambung tanpa sub judul Bahan dan Metode, Hasil, dan Pembahasan. Catatan hasil penelitian dan ulasan ditulis tidak lebih dari 12 halaman (termasuk gambar dan tabel), sedangkan hasil penelitian dan ulas balik ditulis maksimum sebanyak 15 halaman, termasuk gambar dan tabel.
Gambar dalam bentuk grafik harus asli (bukan hasil fotocopi) dengan ukuran lebar (sisi horizontal) maksimum $8,5 \mathrm{~cm}$. Angka dan huruf keterangan gambar menggunakan huruf bertipe Times New Roman berukuran 8 point. Gambar dalam bentuk foto hitam putih dicetak pada kertas licin berukuran kartu pos. Gambar foto yang akan dicetak dikenakan biaya dan dibebankan kepada pengirim naskah. Angka dan huruf yang digunakan dalam tabel juga menggunakan huruf bertipe Times New Roman berukuran 8 point.

Nama organisme (Indonesia/Daerah) yang tidak umum dikenal harus didikuti nama ilmiahnya pada pengungkapan pertama kali.

Daftar pustaka ditulis memakai sistem nama-tahun dan disusun secara abjad sesuai dengan ketentuan berikut:

Jurnal

: Nama penulis. Tahun. Judul (huruf kecil kecuali huruf pertama). Nama Jurnal. Volume, Nomor : halaman.

Buku

: Nama penulis. Tahun. Judul (huruf besar pada tiap kata, kecuali kata penghubung). Edisi. Penerbit. Kota Penerbit.

Bab dalam buku : Nama penulis bab. Tahun. Judul bab (huruf kecil kecuali huruf pertama). Di dalam : nama penulis buku. Judul buku (dengan huruf besar pada tiap kata, kecuali kata penghubung). Edisi. Penerbit. Kota Penerbit. Halaman.
Abstrak
: Nama penulis. Tahun. Judul (huruf kecil kecuali huruf pertama). Abstrak pada pertemuan/jurnal/prosiding. Tempat pertemuan. Waktu pertemuan. Halaman.
Prosiding
: Nama penulis. Tahun. Judul (huruf kecil kecuali huruf pertama). Di dalam: Prosiding (pertemuan ilmiah). Volume. Tempat pertemuan. Waktu pertemuan. Halaman.

Skripsi/Tesis/Disertasi: Nama penulis. Tahun. Judul (huruf kecil kecuali huruf pertama). [Skripsi]. Nama Fakultas dan Perguruan Tinggi. Tempat/Kota.

Informasi Internet : Nama penulis. Tahun. Judul (huruf kecil kecuali huruf pertama). Alamat homepage (http). Tanggal terakhir di up date. 


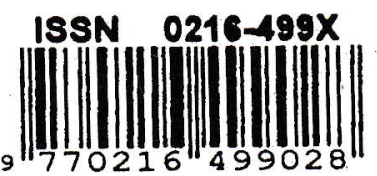

